\title{
Vi var folket. Møde med østeuropæerne 30 år efter Murens fald
}

\author{
Thomas Ubbesen \\ København: Gyldendal 2019 \\ 304 sider. ISBN 9788702284874
}

Omtalt av Mette Skak [phd, lektor ved Institut for Statskundskab, Aarhus Universitet,msk@ps.au.dk]

Den danske TV- og radiojournalist Thomas Ubbesen har via sine utallige reportager fra borgerkrigene i eks-Jugoslavien, Ruslands annektering af Krimhalvøen og klodens andre brændpunkter gjort indtryk på denne anmelder som uhyre dygtig og engageret. Det samme har hans kone Anne Haubek gennem radiomagasinet Europa lige nu. Ubbesens bog tager læseren på en betagende dannelsesrejse gennem hele det postkommunistiske Europa undtagen Baltikum med det formål sammen med en lang række lokale samtalepartnere at gøre status ved 30-året for Murens fald 9. november 1989: Hvordan var det at leve under kommunismen? Hvordan er det nu? Årstiden for ægteparrets Østeuropa-odyssé signalerer hverken svømmepøler eller paraplydrinks: det var i efteråret og vinteren hen over julen og nytåret 2018-2019. Bogen består af 53 velskrevne punktnedslag, hvor parret ved hjælp af deres netværk af lokale bekendte fra journaliststanden eller ved tilfældets hjælp bringer læseren tæt på den generation, der i 1989 bragte kommunismen til fald med slagordet: "Wir sind das Volk!« Derudover er der en hel del sigende fotos fra rejsen.

Formelt er dette således hverken et bidrag til samfundsvidenskaben eller områdestudiet af det østlige og centrale Europa. Men bogens begavede og ligefremme fremstilling formår til gengæld at skærpe rejselysten og fremme læserens empati for befolkningerne sydøstpå. Dermed være ikke sagt, at ægteparret er ukritiske; slet ikke når de konfronteres med den brovtende polaks "Islam Leute nix hier! «-tese om, hvad der udmærker nutidens Polen. Eller når de på denne måde gør status: „Polen ældes. Landet har EU's måske laveste fertilitetsrate, man får nærmest ingen børn, selv om alle er romersk-katolske i alvorlig grad og derfor sådan set ikke burde bruge prævention. Men 'burde' ser ud til at være død i PiS-land" (s. 37). PiS er den polske forkortelse for regeringspartiet Lov og Retfærdighed.

Portrættet af den hviderussiske virkelighed under overfladen er lige så ramsaltet, selv om mediet herfor er en overraskende munter kvinde ved navn Galina. Hun beretter om "forskellige former for mellemmenneskelig vold, fra regimets side, men 
især fra det modsatte køns side; fra mænd, fra hendes egen mand. Hun siger, at vold gennemsyrer hele den russiske kultur" (s. 67f.). En overgang engagerede hun sig i at få indført lovgivning mod vold i familien. Men så gik den ultimativt Stærke Mand, som der står med en henvisning til Lukasjenko, på banen og pralede med, at han sørme da havde banket sin egen søn. Med det faldt hendes kampagne til jorden. Alligevel bedyrer hun som en af få, at selv om Lukasjenko er en nar og en taber, er det hele da blevet langt bedre nu end under Sovjet. Hendes børn kan rejse, hun kan frit læse Solsjenitsyn, Sakharov eller Sjalamov eller bruge nettet i stedet for systemets endeløse løgnestats-tv (s. 70). Åndsfriheden trives bedre nu.

Den mest deprimerende læsning er nok kapitlerne om det ludfattige Moldova med det endnu værre sovjetiske frilandsmuseum Transnistrien i baghaven. Ude i en af Moldovas trøstesløse landsbyer møder Ubbesen og Haubek den 62-årige Nadia, der tilbringer juledagene med at sidde i syv graders frost og faldbyde friskost fra hendes elskede ko Shoshana. Ideologisk havde hun ikke noget med kommunismen at gøre, men hun husker tiden dengang som en tid med sjove fester og sammenkomster. Nu har hun ud over koen kun lidt høns, gæs og så en kærlig og hjælpsom søn som livline. Forfatterne anfører (s. 174), at Moldova nu er dobbelt så fattigt som Albanien, der jo $i$ årtier havde bundrekorden i levestandard.

Den mest skræmmende læsning er ud over kapitlerne om Hviderusland nok dem om Albanien under Enver Hoxha - skræmmende, men velgørende som påmindelse til alle os fjolser på fortidens venstrefløj, der bildte os ind, at maoisme og stalinisme a la Hoxha var en anderledes værdig og ægte "socialisme" modsat Bresinjevs korrupte og forstenede Sovjetmarxisme. Ubbesen gengiver det daværende albanske sikkerhedspoliti Sigurimis nøgterne protokol om dets åbenlyse justitsmord på kvinden Hatije Tafaj, der efter langvarig tortur gik fra forstanden og siden begik selvmord. Ifølge Ubbesen og Haubeks albanske kilde levede Hoxha og fruen selv et sært liv i Blloku, en eliteghetto midt i Tirana, hvor de 3-4 familier, der tilsammen sad på al magten, terroriserede resten af befolkningen i den efterhånden totalt glemte og isolerede småstat, alt imens de havde deres egne indbyrdes intriger kørende med pludselige forsvindinger til følge. Eller Mehmet Shehus "selvmord".

Noget af det herlige ved Ubbesen og Haubek er, at de udstiller den selvfedme, der besjælede dem selv som unge hippie-tilrejsende fra vores nordiske komfortzone under den kolde krig i mødet med datidens Østeuropa, konkret den rumænske provinsby Tulcea (s. 188). I nutiden præges Rumænien af, at landets "socialdemokrater" gør alt for at rulle kampen mod korruptionen tilbage, og hverken i Bulgarien, Montenegro eller Kosovo går det meget bedre. Overordnet giver bogen indtryk af, at Murens fald i stedet for frihed, økonomisk fremgang og værdighed har banet vejen for uslinge som Ungarns Viktor Orbán. Kun vedrørende navngivningen af Nordmakedonien fik den sunde fornuft en chance. Ellers bliver man som læser temmelig desillusioneret - eller rettere: det står klart, at den nulevende generation af øst- og centraleuropæere, der blev født og voksede op under kommunismen, bærer 


\section{6 | METTE SKAK}

på politiske og økonomiske traumer - ofte selvoplevet sult! - samtidig med, at de hver dag kæmper med at navigere i de nye samfundsvilkår. Måske dramaet bunder i det samme som Henrik Ibsens teaterstykke Vildanden, her den kommunistiske livsløgn, der forsvandt og hensatte folk i chok - mindre livsduelige end før. Under alle omstændigheder skal herfra lyde en tak for udgivelsen af $V i$ var folket som uhyre vedkommende læsning om vore naboer sydøstpå. 